\title{
Insette uit die Toegepaste Linguistiek vir'n kursus vir akademiese doeleindes
}

\author{
Dr. Ninon Roets, Dept. Linguistiek en \\ Literatuurwetenskap, RAU
}

\begin{abstract}
By die RAU, soos by vele ander universiteite, het daar die afgelope aantal jaar 'n behoefte ontstaan aan 'n oorbruggingskursus in Afrikaans vir nie-Afrikaanssprekendes. Die ontwerp en aanbieding van hierdie kursus was die verantwoordelikheid van die skrywer en die Taaldiens aangesien die Departement Afrikaans gevoel het dat hulle nie oor die deskundigheid beskik om 'n tweedetaalkursus te skryf of aan te bied nie. In die soektog na 'n teoretiese begronding vir die kursus is daar bevind dat die Toegepaste Linguistiek die mees gepaste onderbou verskaf.
\end{abstract}

'n Deeglike behoeftebepaling onder studente en dosente en 'n ontleding van die studente se taalvaardigheidstoetse het gedui op 'n behoefte an die ontwikkeling van die reseptiewe vaardighede, luister en lees, en die uitbou van 'n akademiese woordeskat. Die produktiewe vaardighede het geblyk minder dringend te wees aangesien die studente toegelaat word om hulle toetse en werkopdragte in Engels te skryf. Hoewel die studente die wens uitgespreek het om ook Afrikaans te kan praat, was dit nie so noodsaaklik vir hulle oorlewing in die akademiese onngewing nie. Vir die behoeftebepaling is die model van Richterich en Chancerel (1977) en die van Munby (1978) gekombineer. Die insigte oor reseptiewe vaardighede is ontleen aan die navorsing van Krashen $(1981,1982,1983,1985,1989)$, Van Parreren (1983), Postovsky (1974) en Gary (1981). Die bevindinge is gerugsteun deur ' $n$ ondersoek wat in 1986 deur Christison en Krahnke in die VSA gedoen is met 80 niemoedertaal universiteitstudente wat in Engels studeer. Die navorsers stel hulle doelwit met hulle studie soos volg:

This article reports on a study done to detemine how nomnative English speakers studying in US colleges and universitics perceive their language leaming experiences and how they use English in academic settings.

(Christison en Krahnke, 1986, p.61) 
Die skrywers het van gestruktureerde onderhoude gebruik gemaak en die tagtig studente wat met taalondersteuningsprogramme besig was gevra hoe hulle hulle Engelse kursusse beleef. Vrae is gevra oor die belangrikheid in rangorde van die verskillende komponente van die kursusse en ook oor die moeilikheidsgraad van verskillende dele van die werk. Die studente en dosente is ook gevra watter soort vakinhoude volgens hulle die grootste rol sou speel om studente toe te rus vir hulle akademiese studie.

Die resultate was insiggewend. Die toetspersone het gesê dat $80 \%$ van hulle akademieverwante taal hoofsaaklik vir luister en lees gebruik is en slegs $20 \%$ vir skryf en praat. Die moeilikste akademiese gebruik van Engels was om na lesings te luister en om te praat. Een van die studente word soos volg aangehaal:

The first semester I understand alnost noling from lecture. That is first tinte I heard English like that. Professors were very hard to undersiand. Mostly I read the book ... After one year now I can understand most of lecture. But I still write bad notes.

Teachers in English classes speak very clear. They want us to understand everything. That is good, but my teachers now not like that. I wish I had heard English like that before, like maybe in lecture or on sape

(op. cit., pp. 73-74).

Die groot meerderheid studente het hulle ten gunste van lewendige, interaktiewe klassituasies uitgespreek en tesame daarmee 'n voorkeur uitgespreek vir werklike leersituasies soos luister na regte lesings of om aan outentieke klasbesprekings deel te neem. Nog ' $n$ insiggewende bevinding was dat studente gevoel het hulle wil eerder leer van bronne en naslaantegnieke (met ander woorde studievaardighede!) as om doelbewus in die taal onderrig te word. Hulle sê, en dit hou verband met die wens dat outentieke materiaal gebruik moet word,

leamers must do $60 \%$ of tie work on their own. The teacher should just facilitate the leaming

(op. cit., p. 73).

\begin{abstract}
First, the evidence confirms that some kind of natural interaction using the language being leaned is regarded as a major meants to leanting the langtage ...

Second, the study suggests that the receptive skills of listening and reading may have greater importance than are ustually attached to them. The students in our survey strongly indicated that they relied on these skills much more heavily than on productive skills... The subjects clearly indicated that speaking and interaction were valuable for leaning the language but that listening and reading were more important in helping them survive in the academic arena.
\end{abstract}


Third, this study provides more evidence for something we are beconing increasingly convinced of, that one of the most imponant qualities in a language teacher is comprehensibility. The teacher who provides a student with a rich, but understood language experience is at least perceived as the one who contributes most to langutage development.

Our subjects reminded us regularly that they have or want lives outside the classroom, that they need and want to interact with Aniericans, and that they' generally experience great difficully in doing so.

Fifth, we need to remind ourselves regularly that students can be valuable sources of information on the language

(op. cit., p. 75-78)

Dit is duidelik dat hierdie bevindinge ook Krashen $(1981,1982,1985)$ en Krashen en Terrell (1983) se invoerhipotese baie sterk steun, veral aangesien hy nie in die artikel aangehaal word nie en daar dus onafhanklik van sy teorieë dieselfde gevolgtrekkings gemaak is.

Uit die Sosiolinguistiek is insigte verkry betreffende die register wat gedek behoort te word in 'n kursus vir akademiese doeleindes. Daar is baie uiteenlopende standpunte oor die hele "register-aangeleentheid" en die saak is nog grotendeels onopgelos. Robinson (1980) spreek haar soos volg daaroor uit:

There are of course, considerable difficulties in attempting to isolate any "langrage of specialisms'. The notion, for example, that a distinctive 'Special register' (appropriate to a special subject) can be identified by contrast with a 'general register' is fraught with confusion

(Robinson, 1980, p. 16).

Halliday druk hom ietwat sterker uit oor die onderwerp en stel sy standpunt soos volg:

(there is) no such thing as general register...merely a category of special purpose languages or langiage varieties

(op. cit., p. 17) 
Daar blyk egter 'n redelike mate van konsensus te wees dat TSD nie noodwendig ' $n$ beperkte register impliseer nie.

This kind of work, namely undertaking 'statistical surveys of tense-frequencies, schence-types, vocabutary, etc.' does provide a framework (in new ESP subjectareas) within which pedogogical selection can be made, even if the principles of such selection are only partly based on the frequency information. Swales remarks, however, that 'sucls work is not now usually thought of as being of nucl direct use ro course design'

(op.cit.,p.19).

Friel en Kirkman (soos aangehaal deur Robinson, 1980) kom tot die gevolgtrekking dat TSD kursusse ontwerp behoort te word met 'n spesifieke teikengehoor in gedagte en dat hulle spesifieke handboeke bestudeer moet word. Vir hierdie doel behoort daar'n registerontleding van hierdie handboeke gedoen te word (loc. cit.)

Uit die vele standpunte wat sy verder oorweeg, kom Robinson (1980) tot die gevolgtrekking dat baie meer as net die leksikon oorweeg behoort te word. Die kardinale faktor blyk die doel te wees wat die bepaler van die linguistiese vorm is. Candlin gebruik die term "communicative purpose" wat daarop dui dat'n mens verder as die teks gaan soek na die kenmerke van die spesiale register en Widdowson pleit vir die gebruik van gespreksanalise en die kommunikatiewe benadering. Halliday steun hierdie benadering en gee die volgende toeligting:

... special languages may be characlerised by different distributions of granmafical paltems, special meanings of generally occuming pattenis and by discourse features of coninected text ... these features would include devices of cohesion such as firstly, moreover, sich as, efc. Mackey, Todd and Trimble refer to rhetorical functions:"Thus we find conmonly the rhetorical finctions of description, definition and classification, and the rhetorical icchiniques of time order, space order and causality. In addition, manuals have two rhetorical features found less comnonly in scientific and techinical writing: the interpretation of illustrations and the rhetoric of instrictions

(op. cil., p. 21-22).

Coffey (1984) laat hom ook uit oor register en sê:

In short, register cannot be used as the main basis for selection, because there is no significant way in which the language of science differs from any other kind of langlage

(op. cit., p. 4).

As algemene onderbou hel die hele taalverwerwingsteorie uit die Psigolinguistiek ook 'n rol gespeel; veral teorieë ten opsigte van oppassertaal en "teacher-talk" en Krashen se invoerhipotese het 'n groot bydrae gelewer.

Krashen se invoerhipotese is alombekend en hoef nie weer in detail uitgestip te word nie, maar enkele kenmerke waaraan die sogenaamde invoer behoort te voldoen, word tog hier aangedui: 
- Betekenisvolle invoer moet natuurlik en interessant wees en moet via betekenisvolle kommunikatiewe aktiwiteite plaasvind sodat leerlinge dit begryp.

- Aktiewe luisteroefeninge moet beklemtoon word omdat daar 'n hoë mate van oordrag blyk te wees tussen reseptiewe en produktiewe vaardigheid (Postovsky 1974, Krashen 1985).

- Begrip gaan produksie vooraf.

- Woordeskat behoort beklemtoon te word. Selfs al ken die leerder nie die sintaksis nie, bied 'n kennis van die woordeskat hom genoeg inligting om genoeg van die boodskap te kan verstaan.

- Invoer moet relevant en war moontlik outentiek wees.

- Invoer moet ryk wees en daar moet baie daarvan wees.

Daar sal verder ook van die Pragmatiek gebruik gemaak word om die verskillende taalfunksies te onderrig.

Met inagneming van al die aangehaalde standpunte en na analogie van bestaande kursusse wat in die praktyk geslaagd is vir Engels, is daar op die volgende sillabus vir 'n kursus in Afrikaans vir Akademiese Doeleindes besluit:

\section{Luistervaardigheid}

Studente sal blootgestel word aan lesingmateriaal wat op band opgeneem is en dan, volgens die volgende riglyne geleer word om inligting te herken, te orden en af te neem:

- Leer om te luister vir semantiese merkers in die teks, byvoorbecld wanneer die dosent 'n hele reeks feite gaan opnoem sal hy 'n merker gebruik soos 'twee onlangse voorbeelde' of 'die eerste' of 'die tweede' of iets soos 'daar is vyf algemene faktore by alkoholmisbruik'. As die student dit hoor, moet hy onmiddellik bedag wees op wat gaan volg.

- Leer om sleutelwoorde in 'n teks te herken en af te neem. Dit is veral belangrik waar groot hoeveelhede stof gedek word wat weer later in 'n handboek nagegaan moet word.

- Leer om opsommings, herhalings en die beklemtoning van feite te herken aan merkers soos 'om saam te vat' of 'oorsigtelik beskou' of 'ons sien dus dat die kernvraagstuk is'.

- Leer om bedag te wees op dinge soos oorsaak en gevolg wat soms in die dosent se woorde versteek is, byvoorbeeld as hy sou sê 'dus', gevolglik', 'derhalwe', 'soos u kan sien'.

- Leer om te weet wanneer 'n dosent twee of meer sake met mekaar vergelyk, deur bedag te wees op woorde soos 'enersyds', 'andersyds', 'in teenstelling daarmee' of 'daarenteen'.

Die aantekeninge wat afgeneem is, moet nou gerekonstrueer word.

- Die student sal geleer word om die opgesomde lesing in te vul en van die nodige skakels, voegwoorde en lidwoorde en dies meer te voorsien sodat dit weer soos 'n volledige teks lyk.

- Deur die teks op allerlei moontlike maniere heen en weer te manipuleer, sal die student hopelik leer om feite van 'vullers' te onderskei en om 'n logiese teks te konstrueer uit 'n warboel gegewens. 


\section{Leesbegrip}

Volgens die diagnostiese toetse wat studente aan die RAU. in hulle eerste jaar afneem, ondervind hulle in die algemeen leesprobleme. Vir die student wat in 'n tweede of soms derde taal 'n teks in die Sosiologie of die Sielkunde moet lees, word die probleem des te groter. Hieraan sal dus veral aandag geskenk moet word.

a) Leestegnieke

Daar sal kortliks aan drie tegnieke aandag gegee word:

- vluglees

- soeklees

- lees vir begrip

b) Globale begrip

Eers sal'n teks in sy geheel behandel word om te bepaal of die studente die algemene strekking daarvan gevolg het.

c) Gedetailleerde begrip

Die teks sal vervolgens deur middel van gestruktureerde opsommings en begripsoefeninge ontleed word om die studente te leer hoe om 'n moeilike teks te benader en dit te probeer verstaan.

d) Woordeboeke

Studente sal deurgaans geleer word on hulle woordeboeke te gebruik om woorde en begrippe na te slaan en soedoende hulle woordeskat uit te brei wat weer tot beter leesbegrip sal lei.

e) Opsommings

Studente sal geleer word hoe om sinvolle opsommings van hulle leeswerk te mak sodat hulle later genoeg inligting het om na te verwys.

\section{Skrytvaardigheid}

\section{a) Skrytkonvensies in Afrikaans}

i) Spelreëls

Die spelreëls sal aan die hand van voorbeelde en oefeninge ingeskerp word.

ii) Formele taalgebruik

Daar sal aandag gegee word aan die konvensies van formele taalgebruik in dokumente sowel as in gesprekke.

iii) Informele taalgebruik

Informele taalgebruik sal met formele taal gekontrasteer word om die verskille uit te wys. 


\section{iv) Register} word.

Verskillende registers sal aan die hand van tekste en oefeninge geïllustreer

\section{b) Soorte skriftelike werk}

Die verskillende soorte skriftelike werk sal geïllustreer en geoefen word, te wete:

i) Memoranda

ii) Verslae

iii) Opstelle

iv) Opsommings

v) Resensies (slegs met BA Tale studente)

vi) Briewe

vii) Akademiese werkopdragte

c) Biblbiografiese gegewens

i) In die teks

ii) In die bronnelys

iii) Verskillende style van verwysing

\section{Taalfunksies}

Daar sal aan die volgende taalfunksies aandag gegee word:

\section{a) Argumentasie}

b) Oorreding

\section{c) Vrae}

d) Versoeke

e) Bevele

f) Suggesties

\section{g) Verskonings}

h) Stellings.

Slegs wanneer 'n kursus van hierdie aard werklik wetenskaplik gefundeer is en 'n stewige teoretiese onderbou het, kan 'n mens hoop om enige mate van sukses te behaal waar dit in twaalf jaar op skool nie bereik kon word nie. 


\section{Bibliografie}

Allen, Virginia French (1983). Techniques in teaching vocabulary. New York. Oxford University Press.

Allwright, R.L., Woodley, M.P en Allwright, J.M. (1988). Investigating reformulation as a practical strategy for the teaching of academic writing. Applied Linguistics, 9/3, pp. 236-256.

Bachmann, L. (1990). Fundamental considerations in language teaching. Oxford. Oxford University Press.

Barr, Pauline, Clegg, John en Wallace, Catherine (1981). Advanced reading skills. Essex. Longman.

Brown, J. Marvin en Palmer, Adrian, S. (1988). The listening approach. New York. Longman.

Budd, Roger (1989). Simulating academic research: one approach to a study skills course. ELT Joumal, 143/1. pp. 30-37.

Chaudron, Craig, en Richards, Jack C. (1986). The effect of discourse markers on the comprehension of lectures. Applied Linguistics, 7/2, pp. 113-127.

Christison, M.A. en Krahnke, K.J. (1986). Student perceptions of academic language study. TESOL Quarterly, 20/1, Maart, pp. 61-81.

Coffey, B. (1984). ESP - English for specific purposes. Language Teaching, 17/1, pp. 2-16.

Davis, Paul en Rinvolucri, Mario (1988). Dictation. Cambridge. Cambridge University Press. 
ETIC. (1978). The teaching of comprehension. (Occasional Paper). London. The British Council,

Ewer, J.R. en Latorre,G. (1969). A course in basic scientific English. London. Longman.

Gary, J.O. en Gary, N. (1981). Caution: Talking may be dangerous to your linguistic health. IRAL, XIX/1, pp. 1-13.

Gass, Susan, M. en Madden, Carolyn G. (reds.) (1985). Input in second language acquisition. Rowley. Massachusetts. Newbury House Publishers.

Hafiz, F.M. en Tudor, Ian (1989). Extensive reading and the development of language skills. ELT Journal, 43/1, January, pp. 4-18.

Hamp-Lyons, Liz. (1983). Survey of material for teaching advanced listening comprehension. TESOL Quarterly, 17/1, pp. 109-122.

Hutchinson, Tom en Waters, Alan (1984). Interface. English for technical communication. Essex. Longman.

Jordan, R.R. (1989). English for academic purposes. Language Teaching, 22/3, pp.150-64.

Krashen, S.D. (1981). Second language acquisition and second language learning. Oxford. Pergamon Press.

Krashen, S.D. en Terrell, T. (1983). The natural approach. San Francisco. Pergamon Press. 
Krashen, Stephen D. (1985). The input hypothesis. Now York. Longman.

Krashen, S.D. (1990). We acquire vocabulary and spelling by reading. Additional evidence for the input hypothesis. Modem Language Joumal, 73/iv, pp. 440-464.

Lebauer, R. Susan (1984). Using lecture transcripts in EAP Lecture Comprehension Courses. TESOL Quarterly, 18/1, pp. 41-54, Maart.

Long, D.R. (1989). Second language listening comprehension: A Schem-Theoretic Perspective. The Modern Language Joumal, 73/i, pp. 32-40.

Munby, J (1978). Communicative syllabus design. Cambridge. Cambridge University Press.

Murphy, John Merton (1985). An investigation into the listening strategies of ESL college students. UMI:Dissertation Information Service. Michigan.

Otto, Stanley (1979). Listening for note-taking in EST. TESOL Quarterly, 13/3, pp. 319-328.

Postovsky, Valerian (1974). The effects of delay in oral practice at the beginning of second language learning. Modem Language Journal, 58, pp 229-239.

Richterich, R. en Chancerel, J-L (1977). Identifying the needs of adults leaming a foreign language. Oxford. Pergamon Press.

Robinson, P.C. (1980). ESP (English for Specific Purposes). Oxford. Pergamon Press. 
http://spilplus.journals.ac.za/

Schifrin, Deborah (1987). Discourse Markers. Cambridge. Cambridge University Press.

Sheal, Peter (1981). Advanced level writing skills for colleges and universities in Africa. Essex. Longman.

Ur, Penny (1984). Teaching listening comprehension. Cambridge. Cambridge University Press.

Van Parreren, Carel (1983). Primacy of receptive skills in foreign language learning. System, 11/3, pp. 249-253.

Wallace, Michael J. (1980). Study skills in English. Cambridge. Cambridge University Presss. 